\title{
Development across the life cycle
}

\author{
O desenvolvimento ao longo do ciclo vital
}

\author{
Christian Kieling*
}

A primary issue in psychiatric clinical practice is the definition of normality. Normality may be defined as utopia, as health (which is more than the absence of disease, as recommended by the World Health Organization), as average. Using a simplistic definition of normality is certainly not the best way to go, as we learn from Brazilian writer Machado de Assis in The alienist, a novel in which physician Simão Bacamarte ends up alone in the Green House asylum after having defined normality as majority. ${ }^{1}$ It is precisely in this arena that a deep knowledge of the typical, expected human development across the life cycle acquires major relevance for child and adolescent psychiatric practice.

Beyond that: we live in an age where several trends and theoretical models have developed - and it is now necessary to bring them together. The very notion of childhood and family as we conceive them today is recent, as shown in the work of Philippe Ariès. ${ }^{2}$ The study of the mind and brain has also seen an explosive growth in the 20th century, with the first half of it focusing essentially on the intrapsychic, and the second on neurobiology. At the same time, the study of social, community, and family aspects has been growing, to the point that the individual, or better, the child, is not just simply a child anymore, but rather a child and his/her circumstances, to paraphrase Ortega y Gasset. ${ }^{3}$

Leon Eisenberg, professor of Child and Adolescent Psychiatry at Harvard, deceased a few years ago, wrote a classical article entitled "Development as an unifying concept in psychiatry." ${ }^{4}$ The same author, a prominent critic of psychoanalysis in the 1970s, published another paper in the British Journal of Psychiatry in the 1980s, criticizing the existence of two kinds of psychiatry: one brainless and the other mindless. ${ }^{5}$ Eisenberg, towards the end of his life, declared that he regretted having been such a harsh critic of psychoanalysis - arguing that psychoanalysis did have a value in teaching his students to listen to their patients.

Eisenberg's major argument was that, from a developmental point of view, it is possible to integrate different areas of knowledge with the ultimate aim of understanding how, why, and why precisely a family seeks help - in addition to giving us hints of why it was not possible for that child, the adolescent, and the family to resolve the problem without resorting to a mental health professional. In this sense, an understanding that takes into consideration biological, psychological, and social aspects - i.e., a biopsychosocial understanding - is essential in psychiatric practice, especially in psychiatric practice dealing with children, adolescents, and their families.

Therefore, it is essential to have knowledge of the development of the central nervous system from as early as fertilization, with the growth of 250 thousand neurons per minute over the 9 months of pregnancy, the process of neuronal and synaptic pruning in the first years of life, and the progressive myelination of the central nervous system. ${ }^{6}$ Similarly, Freud's lessons about psychosexual stages (oral, anal, phallic, latency, and genital phases) is

\footnotetext{
* Department of Psychiatry, Universidade Federal do Rio Grande do Sul (UFRGS), Porto Alegre, RS, Brazil. E-mail: ckieling@ufrgs.br Financial support: none.

This paper was developed for the written test of the competition examination for the position of locum tenens Professor of Child and Adolescent Psychiatry at the Department of Psychiatry and Legal Medicine of Universidade Federal do Rio Grande do Sul, held on July 17, 2013 (the original, handwritten draft is available as online supplementary material).

Suggested citation: Kieling C. Development across the life cycle. Trends Psychiatry Psychother. 2014;36(2):59-62. http://dx.doi.org/10.1590/2237-6089-2014-1001
} 
also extremely important, as are the developments of the Freudian theory with Melanie Klein and schizoparanoid and depressive positions, Bion and the mother's container function, transforming beta elements into alpha elements, Winnicott's notion that a sufficiently good mother is essential for the development of a true self. ${ }^{7}$

Going a bit further, understanding the family system (and its history), as well as its integration in the broader community, is also relevant. Erikson expands Freud's psychosexual stages to define different crises over the life cycle: basic trust vs. mistrust; autonomy vs. shame; initiative vs. guilt; industry vs. inferiority; identity vs. role confusion; intimacy vs. isolation; generativity vs. stagnation; integrity vs. despair. ${ }^{8}$ Based on all these theoretical frameworks, we can more securely get ready to treat children, adolescents and their families, always keeping in mind, as argued by Salvador Minuchin, that the map is not the territory - it only represents it. ${ }^{9}$

Treating infants and their parents, for example, has to take into consideration the life cycle stages that occurred before conception. As suggested by Selma Fraiberg, in every nursery there are ghosts, even when not invited. ${ }^{10}$ Therefore, a transgenerational perspective is essential for a better understanding of complaints such as insomnia, colic, and difficulties interacting. We should be attentive not only to what is reported by the mother and father, but also to how they act and interact. From a neurobiological point of view, attention to nonverbal aspects makes the most sense, as it is through nonverbal language that we may gain access to the parents' early childhood experiences - experiences that remained recorded on their procedural memory more than on their declarative one. Moreover, vital transitions and crises experienced not only by the parents (abdicating their roles as children), but also by grandparents and other members of the family, should also be considered.

Other useful areas of knowledge include the baby's organizers, according to Spitz (smiling, anxiety to strangers, the "no") and the separation and individuation processes described by Mahler. ${ }^{7}$ Combining this knowledge with notions of the family life cycle is also necessary. The family life cycle starts when the young adult leaves the family of origin and establishes marriage with no children (it should be noted that, in Brazil, as well as in other developing countries, leaving home can mean moving to a new house in the same property for a good portion of the population). After this adjustment period for the husband and wife, the arrival of the first child places them in another stage of the life cycle. Centripetal forces usually act at this moment, when the family tends to agglutinate because of the arrival of a new member.

The evaluation and treatment of preschoolers also requires knowledge of the characteristics of normal development. Understanding cognitive development (for example, as suggested by Piaget, divided into [1] sensorimotor, [2] preoperational, [3] concrete operational, and [4] formal operational) ${ }^{11}$ is important not only for evaluation, but also when offering the patient's and his/her family's feedback and psychoeducation not to mention treatment. Using either more clinical/ psychopharmacological or more psychotherapeutic approaches, entering the child's fantasy and playing world is essential. This is true both from the point of view of identifying symptoms for the establishment of a formal diagnosis (trauma, for example, may be reenacted in play, as recognized by the new operational criteria for post-traumatic stress disorder in the 5th edition of the Diagnostic and Statistical Manual of Mental Disorders [DSM-5]); and for an understanding of play as free association, as illustrated by Freud - an 18-month old child that plays with a spool may be symbolizing distancing and approximating. ${ }^{12}$

Integrating knowledge in the treatment of schoolage children is also paramount. Being alert to aspects of the oedipal conflict and its repercussions in latency is extremely important while evaluating symptoms in this age group. Understanding the meaning of fears, anxiety, obsessions, or compulsions may help us distinguish between the normal and the pathological. At the same time, knowing that disorders such as attention-deficit/ hyperactivity disorder (ADHD) are characterized by a maturation delay in cortical thickness (about 3 years of delay, especially in the prefrontal cortex, in relation to controls with typical development, according to a cohort study conducted by the U.S. National Institute of Mental Health) is also important when evaluating a preschooler. ${ }^{13}$ There is also evidence that children born in the beginning of the academic year have a higher likelihood of being diagnosed with ADHD after controlling for all other variables, only because they are less "mature."14 Families with small children have to face the start of school and other community activities. At this point, tension related to comparisons between families may emerge. The use of psychopharmacological drugs by a child, for example, has an impact on how parents see themselves in relation to other parents in the same school.

The treatment of adolescents should also take into consideration biopsychosocial aspects of this stage of the life cycle. In addition to maturation of the nervous system, at this stage hormonal changes take place that will culminate in puberty. Body changes urge the adolescent to deal with this strange, disturbing phenomenon - and indeed, he/she will be experiencing a strangeness, not only for him/herself, but also for the people living with him/her. As suggested by Blos, this is the stage when a second individuation process takes 
place, i.e., when the adolescent has to disidentify from childhood and from his/her parents. ${ }^{15}$ Meltzer argues that the adolescent inhabits four worlds: family (in which he/she remains as in latency); adults (in which he/she is a pseudo-adult); other adolescents (groups of the same sex at first, then couples); and his/her own world (a refuge for reflection). ${ }^{16}$ In these oscillations, families with adolescents have to prepare for some comings and goings. Parents have to be ready to welcome the adolescent back after they have been discarded and depreciated - they have to survive the adolescent, as argued by Winnicott. ${ }^{17}$ And the same principle is valid for us, therapists: we have to be ready for no shows and acting outs, even though always attentive to the meaning of these communicative actions.

When children are in adolescence, parents are reaching middle age, and grandparents, old age. The "maturescence" stage has been referred to as a way back from adolescence. ${ }^{18}$ It is important to be attentive to this when we see a father or mother who may, at the same time, idealize and envy aspects of their adolescent child. The Australian model of mental health of young people suggests that the cutoff for child/adult services should be at around 25 years of age. ${ }^{19}$ This makes sense not only from the point of view of the incidence/first episode of mental disorders, but also because of the invasion of adolescence into young adulthood. The so-called "adultescence" is characterized by economic independence with fewer advances in emotional aspects. Moreover, it is increasingly common, as a result of marketplace demands, that young adults will stay longer at their parents' homes.

The moment when children leave home is another landmark. The so-called empty nest syndrome may cause parents to get ahead and develop mechanisms that will make their children stay longer, e.g., a mother who renovates the daughter's room when the latter is ready to leave home. Approaches that carry this understanding - e.g., individual systemic psychotherapy - have more and more shown to be promising and necessary when treating children, adolescents, and young adults (but not only these age groups)..$^{20}$

Knowing aspects of the individual life cycle of each family member and of the family system as a unit is extremely important. The death of a family member, for example, has a tremendous impact on all others. Whether death is the result of a slow process (with stages such as denial, anger, bargaining, depression, and acceptance, as suggested by Kübler-Ross) ${ }^{21}$ or an unexpected, acute event, it will certainly have repercussions in the whole family system, and perhaps beyond it. Thus, having knowledge of vital crises also helps us understand accidental crises of the life cycle, as it provides us with elements to understand how a child, adolescent, and their families deal with stressors. Therefore, as suggested by Carter \& McGoldrick, ${ }^{22}$ we can outline the family life cycle using vertical elements (transgenerational, not only family, but also community elements) and horizontal elements (vital and accidental crises) (Figure 1).

\section{SYSTEM LEVELS}

\section{Vertical stressors}

1. Social, cultural, political, economic (gender, religion, ethnicity, etc.)

Family patterns, myths, secrets, and legacy

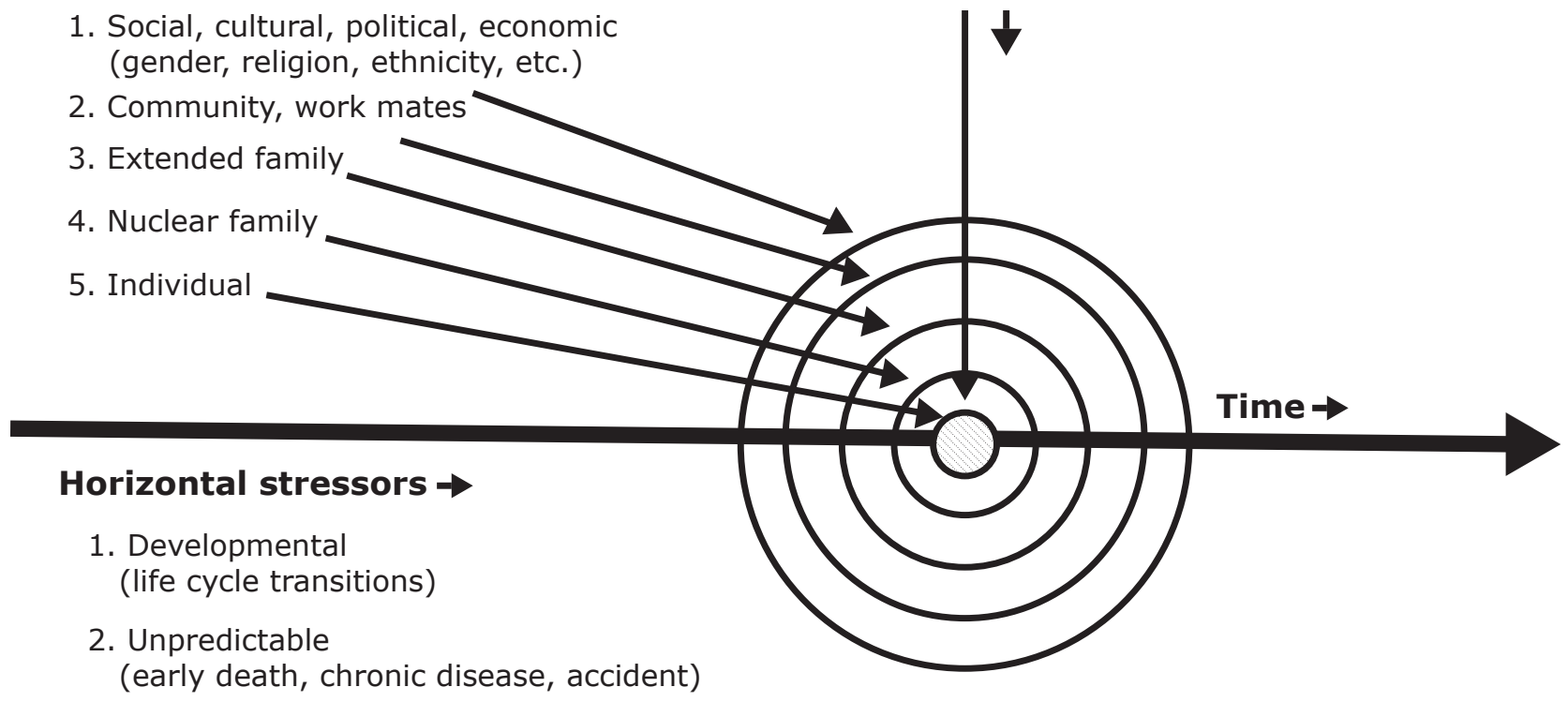

Figure 1 - Vertical and horizontal stressors of the family life cycle. ${ }^{22}$ 
In sum, integrating knowledge and seeing children and adolescents as individuals undergoing major transformation allows us to conceptualize cases thinking of their diagnosis always in the gerund form, as taught by Prego e Silva. ${ }^{23}$ Moreover, it helps us achieve a broader understanding of the integration of children and adolescents in their family and social contexts. All this with the objective of engaging patients, family members, and the broader community (school, neighbors) in effective treatment strategies to reduce suffering and promote the full development of those who are starting their journey across the life cycle.

\section{Acknowledgements}

Christian Kieling receives research support from Brazilian governmental agencies Conselho Nacional de Desenvolvimento Científico e Tecnológico (CNPq), Coordenação de Aperfeiçoamento de Pessoal de Nível Superior (CAPES), and Fundação de Amparo à Pesquisa do Estado do Rio Grande do Sul (FAPERGS); he also receives royalties from Artmed and Manole. The author is grateful to all those who presented him to the authors here cited, especially Professor Maria Lucrécia Scherer Zavaschi, for introducing him to the work of Leon Eisenberg. He also thanks medical student Lucas Battel for transcribing the original manuscript.

\section{References}

1. Machado de Assis JM. Obra Completa. Rio de Janeiro: Nova Aguilar; 2008.

2. Ariès P. História social da criança e da família. $2^{a}$ ed. Rio de Janeiro: Guanabara; 1986.

3. Ortega y Gasset J. Meditações do Quixote. São Paulo: Livro IberoAmericano; 1967.
4. Eisenberg L. Development as a unifying concept in psychiatry. $\mathrm{Br}$ J Psychiatry. 1977;131:225-37.

5. Eisenberg L. Mindlessness and brainlessness in psychiatry. $\mathrm{Br}$ J Psychiatry. 1986;148:497-508.

6. Bear MF, Connors BW, Paradiso MA. Neurociências: desvendando o sistema nervoso. Porto Alegre: Artmed; 2008.

7. Laplanche JB, Pontalis J. Vocabulário da psicanálise. São Paulo: Martins; 2001.

8. Erikson EH, Erikson JM. The life cycle completed. New York: W.W. Norton; 1997.

9. Minuchin S. Famílias: funcionamento e tratamento. Porto Alegre: Artes Médicas; 1982.

10. Fraiberg S, Adelson E, Shapiro V. Ghosts in the nursery. A psychoanalytic approach to the problems of impaired infant-mother relationships. J Am Acad Child Psychiatry. 1975;14:387-421.

11. Bee $H$, Boyd D. A criança em desenvolvimento. Porto Alegre: Artmed; 2011.

12. Freud $S$. Além do princípio do prazer. Rio de Janeiro: Imago; 1996.

13. Shaw P, Eckstrand K, Sharp W, Blumenthal J, Lerch JP, Greenstein $D$, et al. Attention-deficit/hyperactivity disorder is characterized by a delay in cortical maturation. Proc Natl Acad Sci U S A. 2007; 104:19649-54.

14. Zoëga $\mathrm{H}$, Valdimarsdóttir UA, Hernández-Díaz S. Age, academic performance, and stimulant prescribing for ADHD: a nationwide cohort study. Pediatrics. 2012;130:1012-8.

15. Blos $P$. The second individuation process of adolescence. Psychoanal Study Child. 1967;22:162-86.

16. Levy R. O Adolescente. In: Eizirik CL, Bassols AMS, editores. O ciclo da vida humana: uma perspectiva psicodinâmica. $2^{a}$ ed. Porto Alegre: Artmed; 2013. p. 167-80.

17. Winnicott D. O brincar e a realidade. Rio de Janeiro: Imago; 1975

18. Montero GJ. Madurescência [clínica da incerteza na meia-idade] In: Eizirik CL, Bassols AMS, editores. O ciclo da vida humana: uma perspectiva psicodinâmica. $2^{a}$ ed. Porto Alegre: Artmed; 2013. p. 207-26.

19. McGorry PD. The specialist youth mental health model: strengthening the weakest link in the public mental health system. Med J Aust. 2007;187:S53-6.

20. Falceto OG, Prado LC, Waldemar JOC, Castiel S, Gonçalves NT, Zanonato $A$, et al. O ensino da psicoterapia de orientação sistêmico-integrativa no Instituto da Família de Porto Alegre. Rev Bras Psicoter. 2012;14:75-85.

21. Kübler-Ross E. On death and dying. New York: Maxwell Macmillan International; 1993.

22. Carter EA, McGoldrick M. The expanded family life cycle : individual, family, and social perspectives. 3rd ed. Boston: Allyn and Bacon; 1999.

23. Zavaschi MLS, Bassols AMS, Bergmann DS, Costa FMdC. Abordagem Psicodinâmica na Infância. In: Elzirik CL, Aguiar RW, Schestatsky SS, editores. Psicoterapia de orientação analítica: fundamentos teóricos e clínicos. Porto Alegre: Artmed; 2007. p. 717-37. 


\section{UNIVERSIDADE FEDERAL DO RIO GRANDE DO SUL \\ FACULDADE DE MEDICINA DEPARTAMENTO DE PSIQUIATRIA E MEDICINA LEGAL}

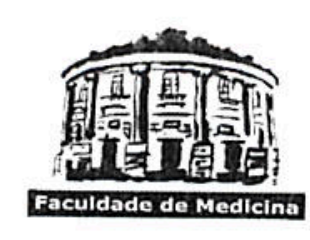

Nome: Chnstian Kieline

Una primeire questar que se choce no atendimento.e ha príhica clinica prizviábriza é a definicas de cormal: dade. Normalidede pode ser définiele cono vtopie, como senide (mais do que ausincia de donze como recomenda a Oreanifacia Mundjal da Sewide), como midia. Utibizar uma definilaw simpleste de normatidende certrimente nä é a method alternotiva, como nos ensina, por examplo, a literatura de Machado de Assis em O Alieniss, ficuä

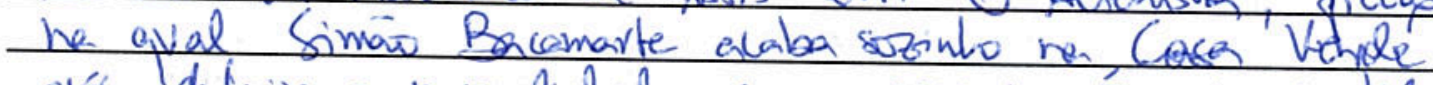
apos difinir a normalidede cono mavona. É nege sentips que o conkecimento phofindo acerca do dexenvolvimento tipico elesprads ao lono do ciclo vital se fat de ciende lele vancie pare a prótica priquíntrica com criances e

Mais do ve isso: vivernos em um imoments em aue diversas correntes e inadelas teonlos se disanvelverem an layo do século $X X$ - e é. preciso integrá-Dos- A própía naca de infánkia e de familia como as concebemos atualmente é reiente, como excmplifierdo na dora de Philipge Ariés. Oestuds da mente e do lénebro também bastal por um. crescimento explorino aw limeo do séculd XX,

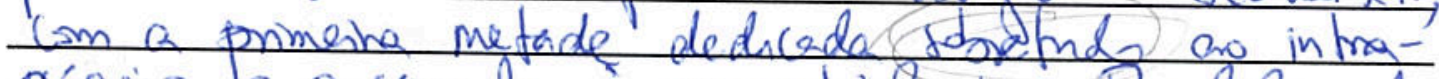

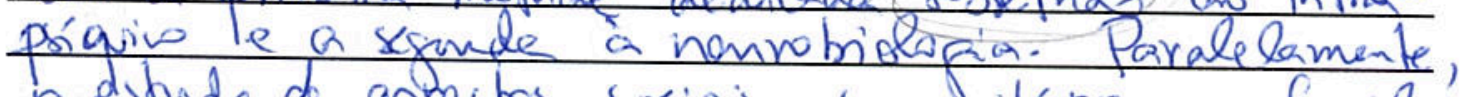
o distude de aspectos sasions, comunitén nos e femilerés veio crevendo, na medida en que o indivídvo, on meIhar dizendo, a crancier, haw é apenan a crianca, mas a crianca e mas circunstencias - paraforse-

Leon Eventbera; professor dituler de psiquiating da infancia e da Jadeleséncia de Unives sidade Aarvard, talecide há alguns anos, tem un arhieo léssios inbitulado "Avelopment as on unifuind concept in psychiatry". O merme dontor, um crítice impostrante da poicanálise na dícada de 1970 , tem um outro 


\section{UNIVERSIDADE FEDERAL DO RIO GRANDE DO SUL FACULDADE DE MEDICINA DEPARTAMENTO DE PSIQUIATRIA E MEDICINA LEGAL}

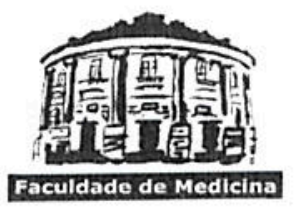

trabsilho publicado to British Joural of Psychiatry na décedea de 1980 em que critica a edosténcios do elnas priquiatrias uma acéfala (brainless) e outros desimentalizada (mindless). Eisomberg, he final de sna vida fet uma declarecoe em que \& desculpave por ter sodó, un critico ta feror de pricanélise argumintave are enta tink sen valor ma medida, en ave "ensinata aos alunos a ouvir sens paciente". Sen argumento prinapal ó de que, ubilizands uma usen desenwolvimental, podanos integrar diferentes conhe cimentos Lom a finalidade ultima de compreender como, por que e por ave neste momento uma familia nos pro unima I além de formecer pistas de por ave nas fos postivel para a crianca, o adrescante elma familia resolverem o problema sem buscar a ajuda de um profishonol de senide inental. Una compreensós ave leve em conte aspectos

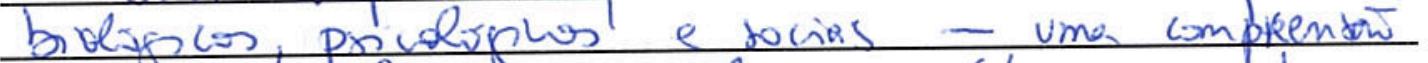
broporiosiocial é essencial na prátiza psiquíbriza, anda mais na prábra priaviábrie com crioncas, a dealescuntes e suos familien. Desk modo, conteles o desentoprimento do sistema nervoso central deste a feundecös, com o consumempo de 250 mil neurohios novos durante os nove meses de gantacon, o procesto de poda dos nemrónios e das conexáes em excerto nos ponmeivos avos de vida e a mielinizacia propinssive do sostema nenoso é essencial. Da mesomb forma, os exrivomentos de Frend fobre os entácoos pescosséxuens fares oral, anal, félice, laténbie e genital) tambers sos muito importantes, berm como Klein e as postés esquitropuranwide e depresnva, Brion e a funcepo conbinente meterne pare trensformar elementos $\beta$ em $\alpha$, Winnicott e a idéia de que uno map supcretemente boa é essencial para o dexencelnimento do verdedeino belf. Indo manis além, a comprinter

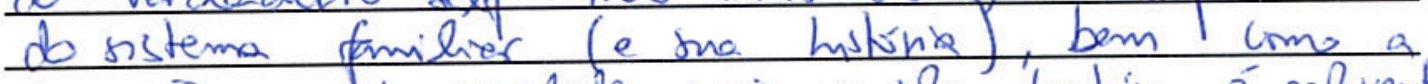
insercéa ra lomunidede mail ample também é relivante. 


\section{UNIVERSIDADE FEDERAL DO RIO GRANDE DO SUL \\ FACULDADE DE MEDICINA \\ DEPARTAMENTO DE PSIQUIATRIA E MEDICINA LEGAL}

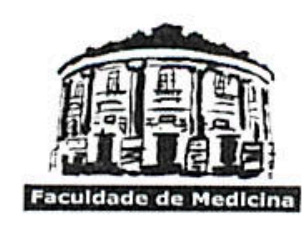

Nome: Christian Keline

Erickson expante os estionos pricossexvais de Frend pasa defonir diferentes crisers as line de cicla vifal:

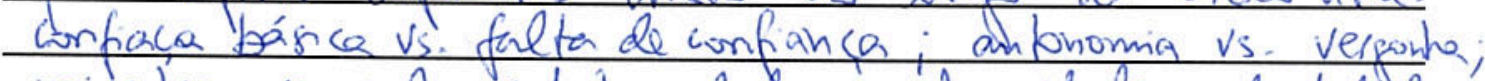
iniciativa vs unlpa, indusmosidedevs.infenwidede; iolentidede vs confusaw de identidede; intimidede vis irolamewto; generatividede vs. estapnatox;e interridede vis. desespeso. Paphindo de todos esses arcabonios ténica podemos chedar com mais segurance ne atendimento do criancas, adelercentes e snos familias, simpre recordando, cono arpemente Salvabor Minuchin, ave o mapa nà é o terilisno - ele apenas

O atendimento de bebés e sens penis, por exemplo, tem que levar em conscieraca etapay do ciclo rikel eve

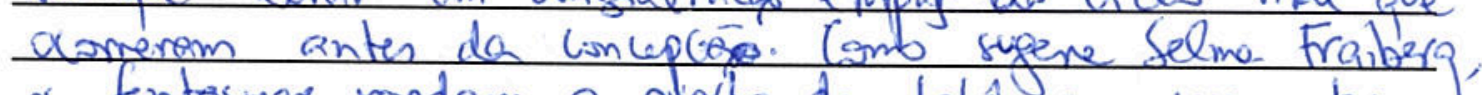
of fantasinors rondam o quifto do bebe sem mesme terem sido convidedos. Assim, ume porspechve transgeracionel é esiencial para o entendimento de gleixon como indónie, chizar, dificuldades ha interacén. Devemos estar atentos nos apenas gare o que a máe \& o pá nos relatom, mos como eles apem e interapem. Do ponto de vista neuro-

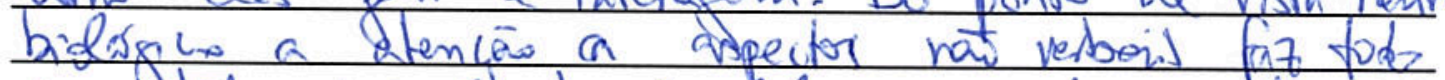
0 sutide, pois é atraves dela ave podevemos ter acesto as vkencias dos pais em sua primeive infancia - vivèninan estas gle fieram reastraden ho menón'a procelnivel mas do que na memsine declarahva. Além disbo, pensar

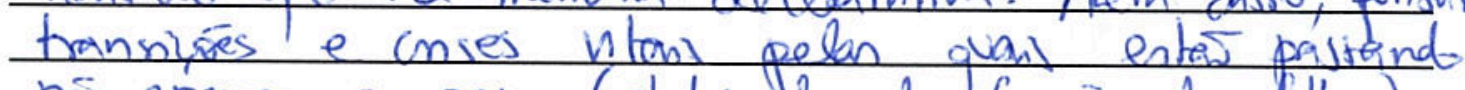
nä apenan os pais (abchionble da sunceo de fillos), mas aís e oubon inembros da famíle eltendide tambím é. importante. Dutros conkecimentos úters sip resem acerca clos organizadores do bebe confeme Spitz (sornso, anviedses a entrantos, o "näas) e das pro cossos de

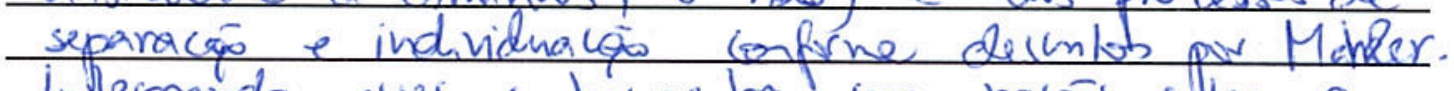
internando esses conkenmentos ism noceses dobre 0 cico vial de tamilia também se fát nevertério: Po demos diter que o ciclo vial de familia tem cono 


\section{UNIVERSIDADE FEDERAL DO RIO GRANDE DO SUL \\ FACULDADE DE MEDICINA \\ DEPARTAMENTO DE PSIQUIATRIA E MEDICINA LEGAL}

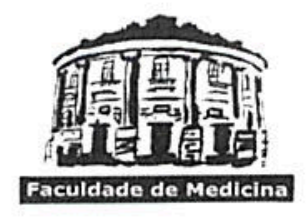

inivo a seńde do adulto lovem da famiha de angern e o estabeleimento do cajal sem fillos (lembiniond que no Bravil aisin como en ontros paises im diten volumento), a saída pode ser para o páhio do cate qara boa parcele da populacáa. Após este período de

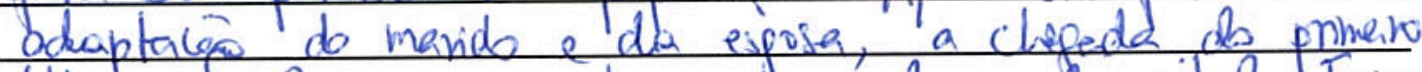
filw of cola em outre etepe do cicle vital Forias inbípetas ioshumam apar nestes momentos, am gie. a fomilis tende a dear mais aglutinede com a A vialiabo e e atendimaito de pré-encolaren também recued o colvulimerto de aspectos do disenvolvimento iscmal. O entendimanto do descruoluments is) nibino (por exemplo, womo souene Pirget, em entósios)

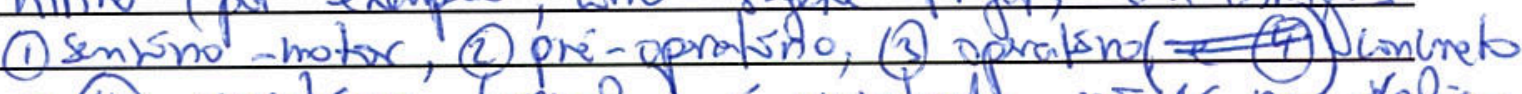

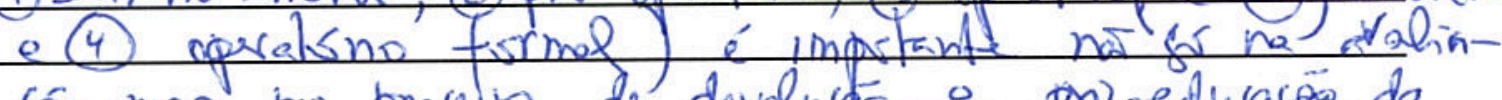

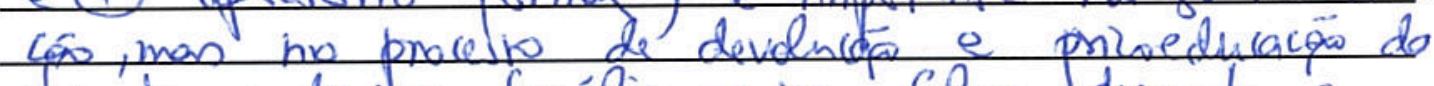
pervande e de ina familia - tem faler dinrounte o

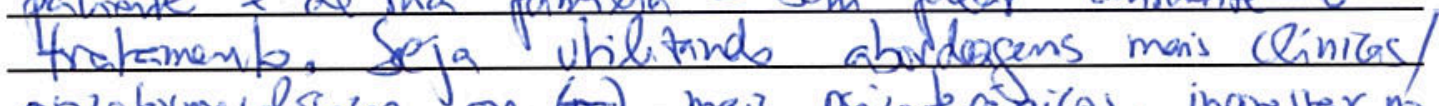

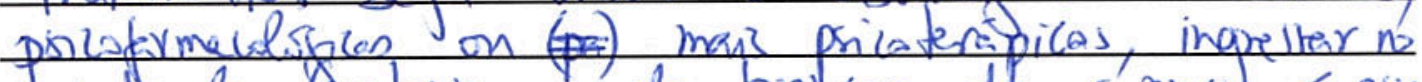

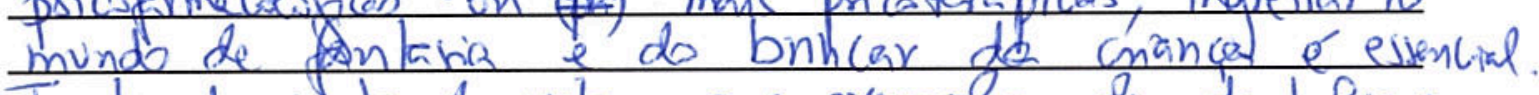
Tanto do ponte de viste, por exemplo, de dentfiar sintomas para a realiteces de un diannosthes formel (trevman, for exumplo, pidem apereces en brincaderien

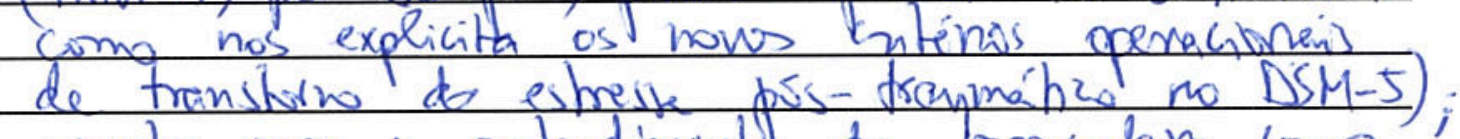
avanto pera o entendiment de brincadora cimo livre-avolialosa, lono já iluitrando nos textos de Frend - uma criance de 18 meses que brmea com un carretel pode estar simboliando distanciamemo e reappoxima cesp.

Intefrar os combecimentos no atendimentos de exibares tambines é fundamental. Estar atemb para arpectos do

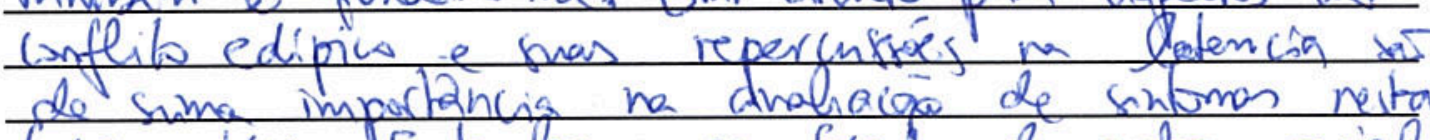

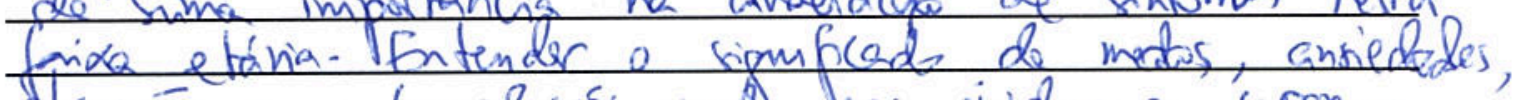

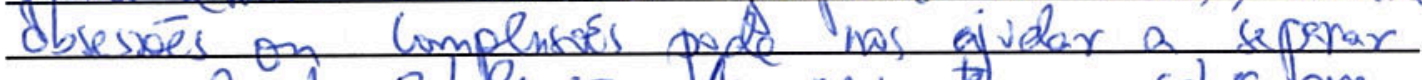
o husimal do paldesioco. Ao mesiro tempo, saber que 


\section{UNIVERSIDADE FEDERAL DO RIO GRANDE DO SUL \\ FACULDADE DE MEDICINA \\ DEPARTAMENTO DE PSIQUIATRIA E MEDICINA LEGAL}

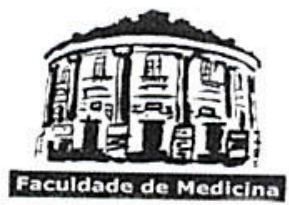

Nome: Chriskan Kielirs

transtornos limo o DAH (ranstove de déficit de atencsp (inperahinida) sin caractentedos por un atraino mahirimal na espestare corhial em torno de 3 aw

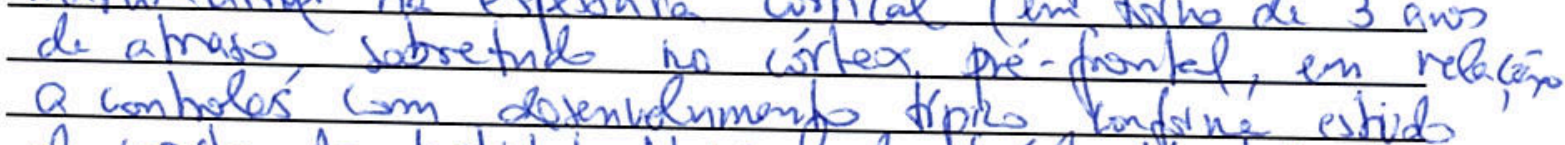
Q conboles com dosenvelumento tipro condstie estido Extados Unidos, também é importande no avahabo do um pé-eiflar. Hé evidénvion de ae crinias rascidan no hicio do ano tến uno probalibidgele man de

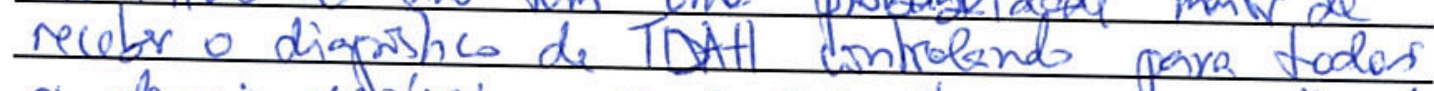
ai demon' variánens, agnas por esterem menos "madome". Nesta etapa, a familise am oflios peguenos, 0

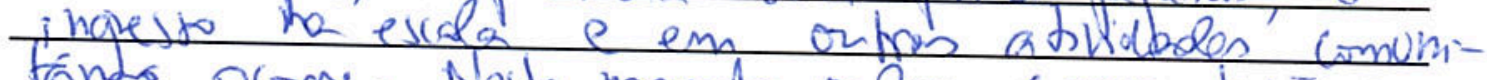
tainds ocorme. Neste nomanto pasom sourgy tentäes re lacionados a comparacea entre fanilion O vio de privofírmecos for una criance, dor exempla, ter Un

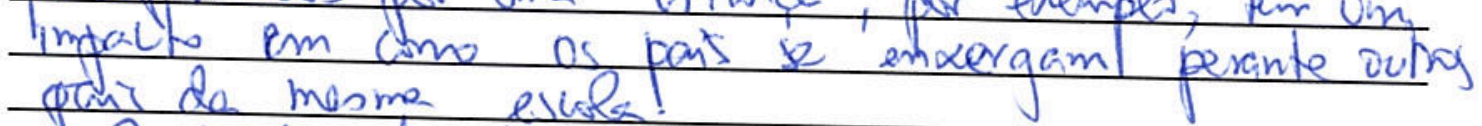
poriz de mesme esioks

em adalescmen tambion deve levar

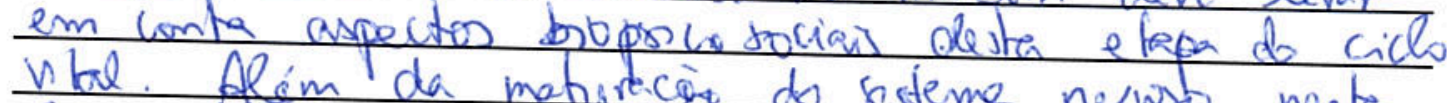

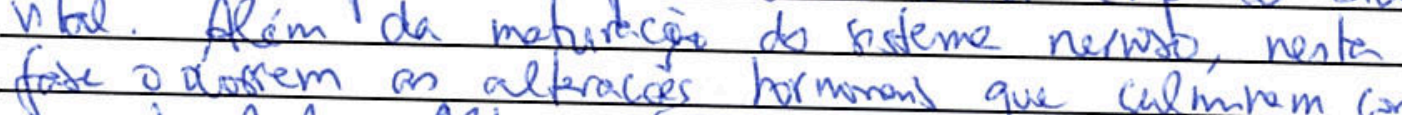
fode o a ofrem an alteracos hormons que culminem cam

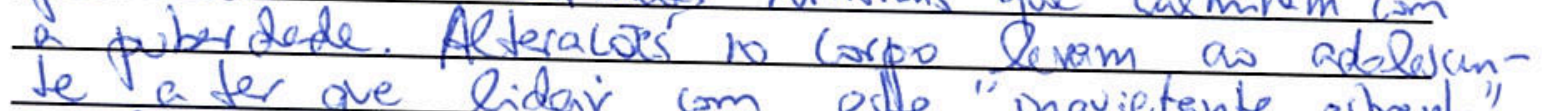
\& da fato que lidar com este "inguietante estrento" $l$, da fato, de paiter un estraitament nä s5 pare si, mon fara do dement que juto com ele/ de la

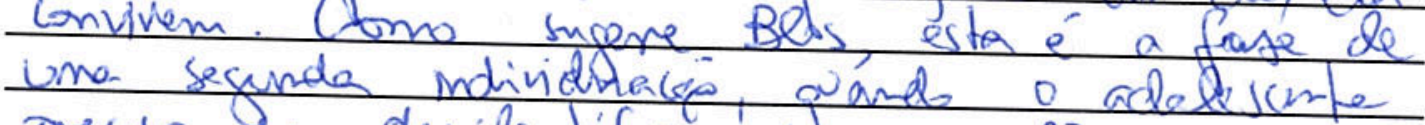
precuse of deridentifor on o inplancia e him

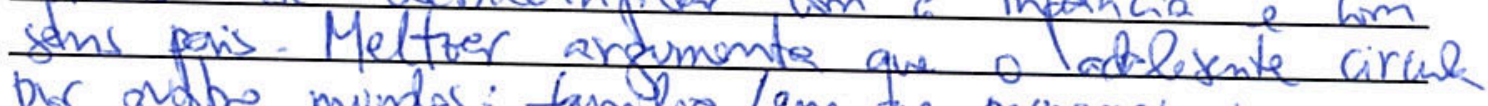
bor oudho mindas: fanilia / am jue permanele cimo no latencos), adulfo (im ore é ptendoblulto); ontoos

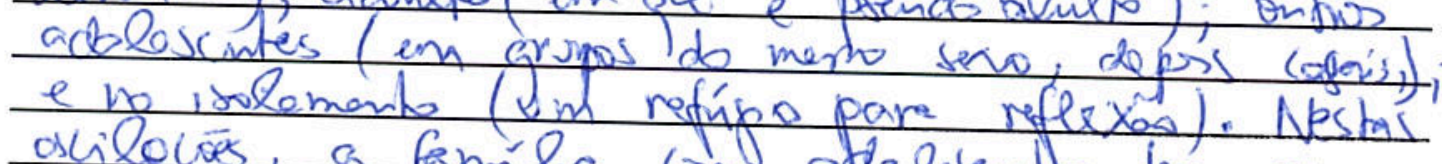
oscilocies, a fennila com adeletenten tem que ester peparala para ides e vindas. OS paig tem 


\section{UNIVERSIDADE FEDERAL DO RIO GRANDE DO SUL \\ FACULDADE DE MEDICINA \\ DEPARTAMENTO DE PSIQUIATRIA E MEDICINA LEGAL}

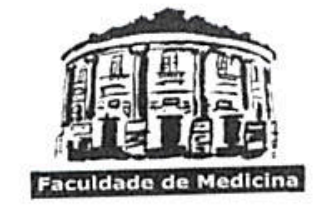

ove estar pnontos pare receber o adcescunte de vata depois de serem descartados e depreciados - tém de "jabreviver ao adolescente", leme nos lembre Winnicott. E o mano vale pare rós, terapenten, ove temis que ester promdiol para antincion, atuasímpicadas destos aloes comunication. Riol momento em que os fithos partam pela addextinvie, a pous estar cheando al mentidade e os avós à velthize. A pastragem pela chemada "modrrescéncia" fri comparade a un camihho de volla de adoletiéncia. E imputarte etar atento sara isto quando relebemos um pen on uma má, ave pode, de mesno termpo, idiallizer e invejar

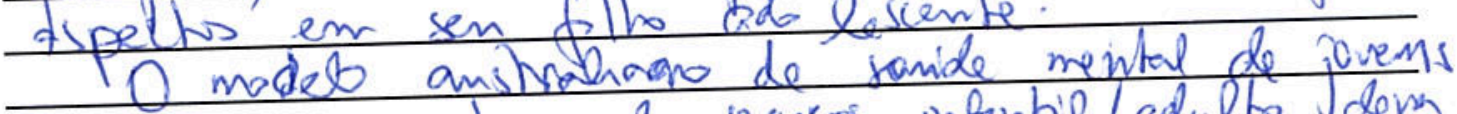
vurese que a guebre de servicos infantil / adulto dew ovoner pelos $24 / 25$ anos de idede. 1so for dentido

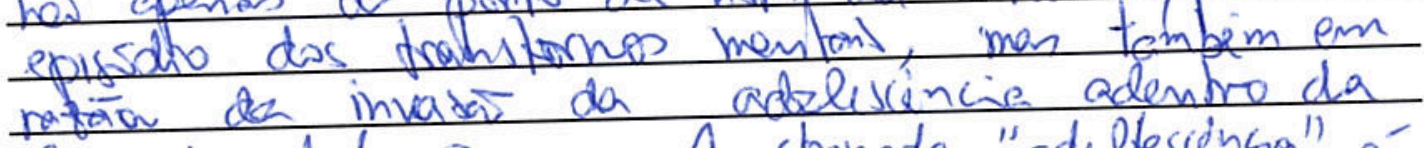
fase de aduto jovem. A chamade "adillesiencia" é caracteniende for tima congusta nos aspectos ecorimicos, sem que os inocibrais tenham aranceds. Além disto, ¿́ cade vea moni comum, liom an expoincion do mercés

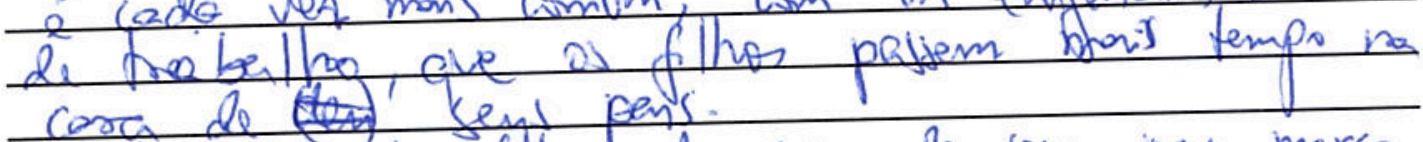
A saride das filluos da cata de sens pers marce un outro momertol A chamada sinchome dol nimb vazo pode faier com gue par te artecipenn e desenwolvem

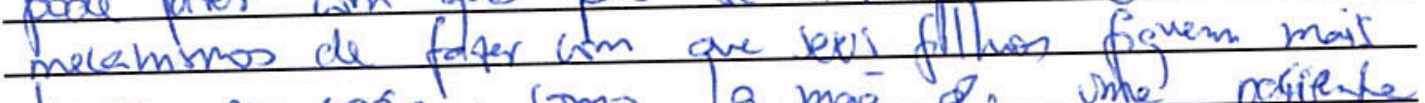

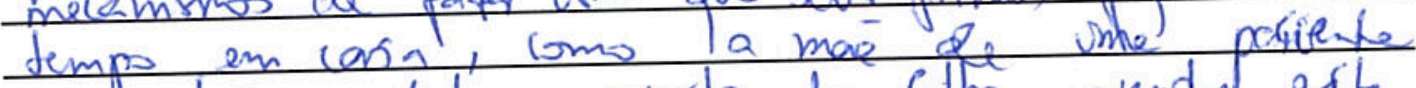
aue redimon tod o guarto de fithe guando efta

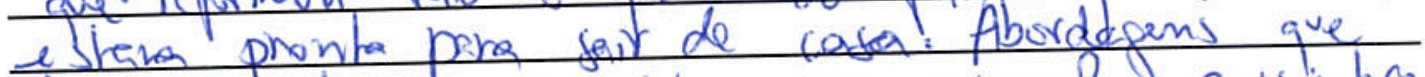
tenham lesta comprensés - jor exemplo, a psicatera gia individual sidteinico - se mostram cadol vet mays promisoras e recostoinen to atendimento de

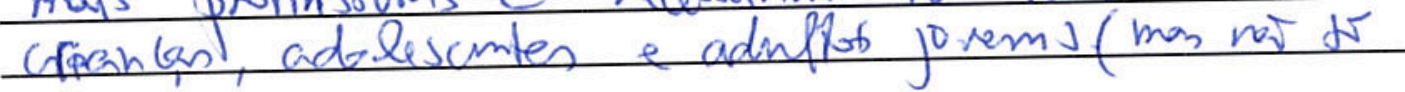




\section{UNIVERSIDADE FEDERAL DO RIO GRANDE DO SUL \\ FACULDADE DE MEDICINA \\ DEPARTAMENTO DE PSIQUIATRIA E MEDICINA LEGAL}

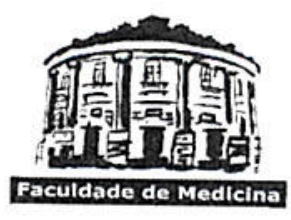

Nome: Christian Keling

destes an pos etános). Conteor as (aspectos do ciclo vital induvidinal de cade um dos imembros a do aclo utal do sistema families corro unidede é muito impsitente. A mirte de un dos inembros da familie, for excumphe, tem um enoine impacto em lados os domeil saja un procisto

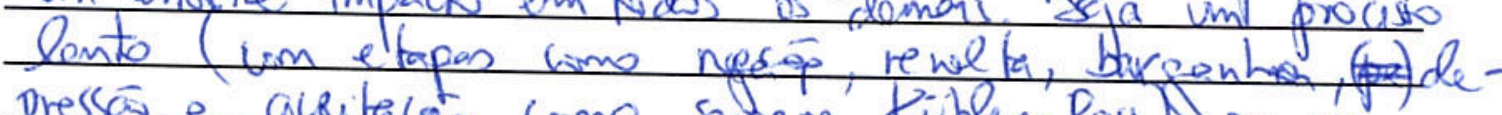

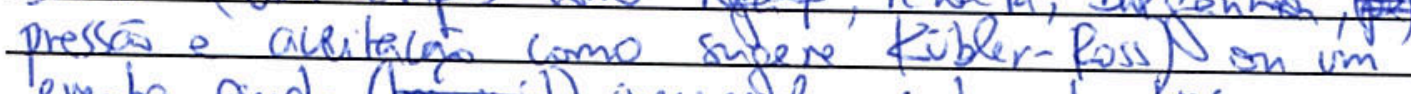

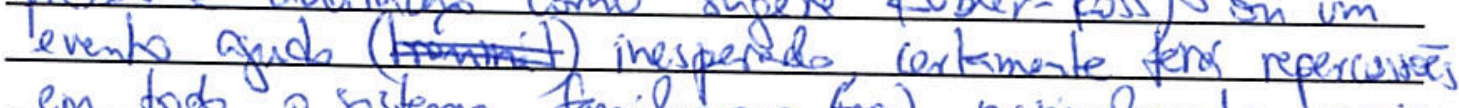
em todo o sistema fanilise e postivelmente, mais alím. Desse modo, combecer as inses hitas ros andulas

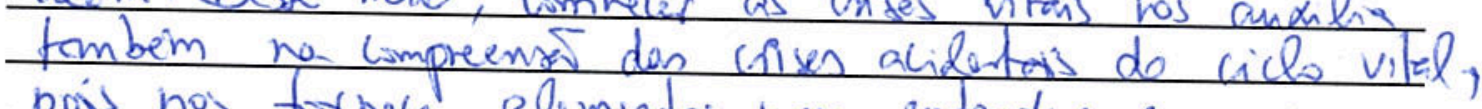
pois nos for nece elimentos pere entender como une

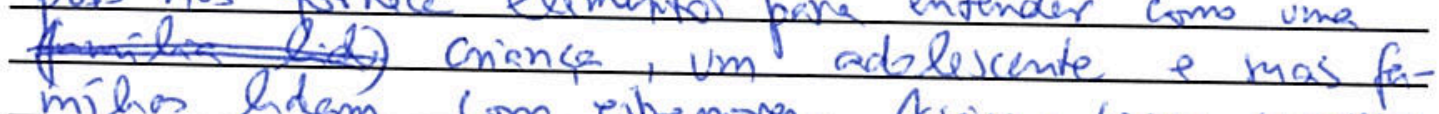
milnos hidam cam eiberores. Asion, womo superem Carter e Moboldnck, pedemis esovemation o Acla

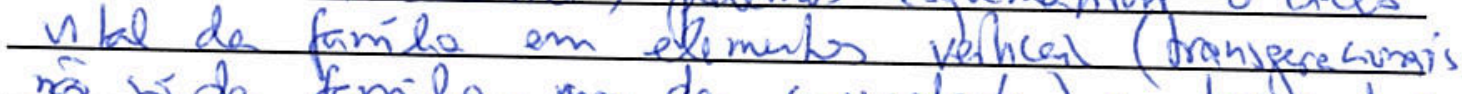

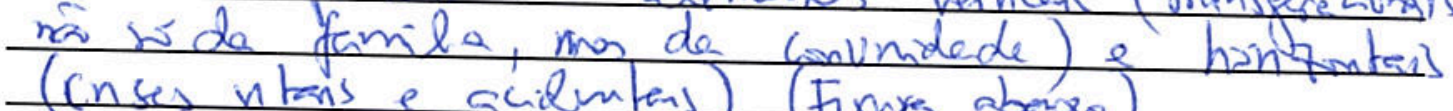

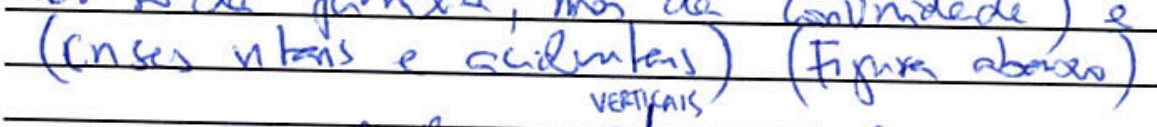

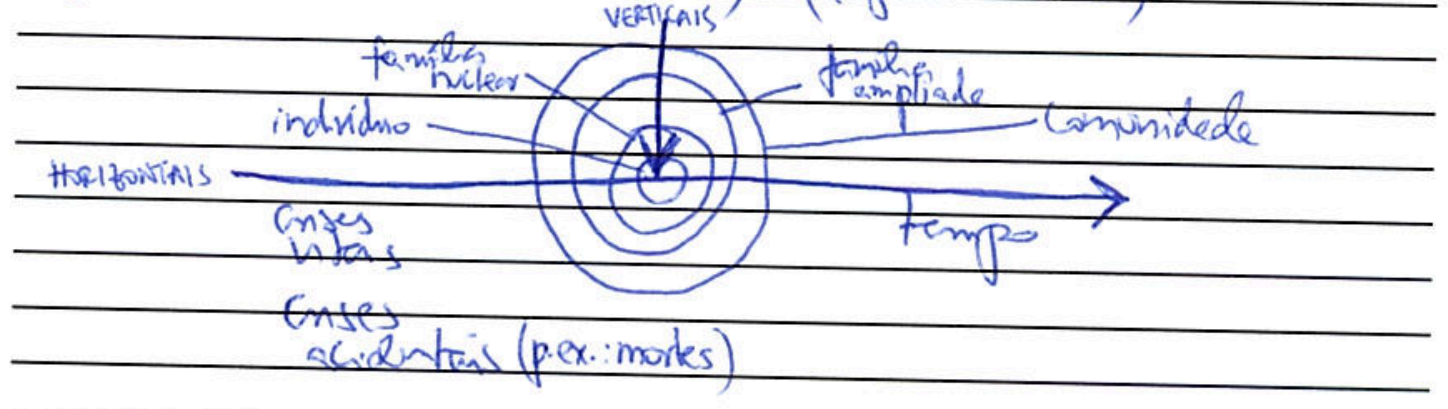

Assion, a integracià de contecimerbs e a concopcón de crivince e do addescente crmo deres am apande draniformacos nos permite

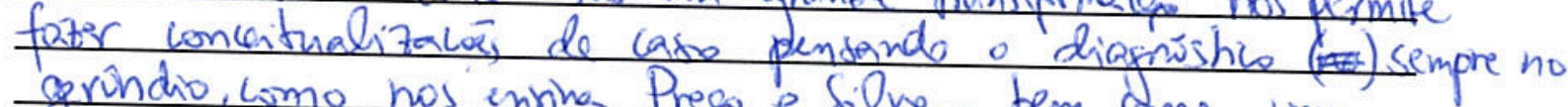
groundio, lomo hos enrino Prego e filve, bem coms une compreenien abrangente da insorcan da crianca e do adolescente em sens contextos familiar e rocial. Tudo isso lom o dojehre de engéjer palientes, familiares e comuri-

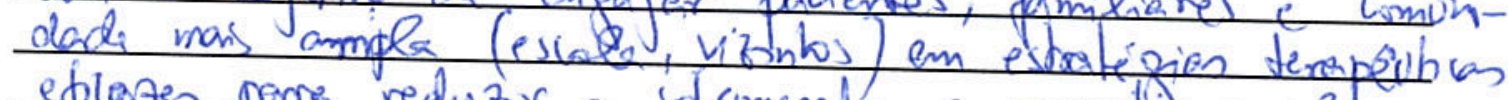

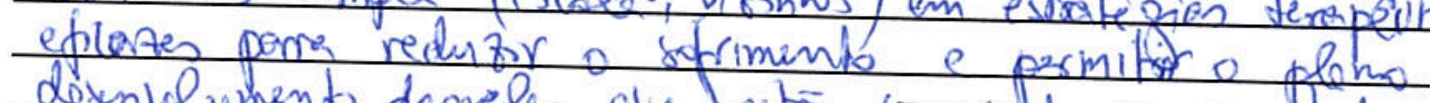

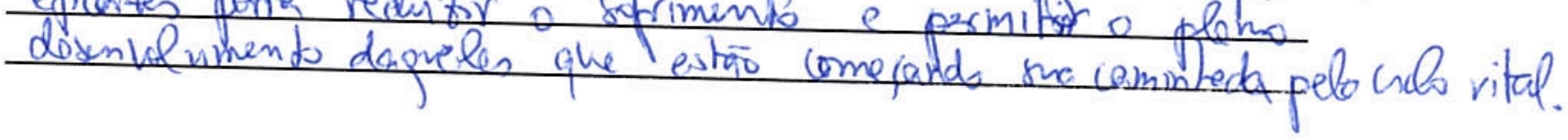

